\title{
LITERATURE REVIEW: PENGARUH PEMBERIAN KOMPRES HANGAT TERHADAP PENURUNAN SUHU TUBUH ANAK DENGAN FEBRIS
}

\author{
Yoga Maulana ${ }^{1}$, Hana Ariyani ${ }^{2}$, Ida Rosidawati ${ }^{3}$ \\ Universitas Muhammadiyah Tasikmalaya ${ }^{1,2,3}$ \\ yogamaulana137@gmail.com
}

\begin{abstract}
ABSTRAK
Demam merupakan permasalahan yang sering terjadi pada anak serta menjadi penyebab kematian tertinggi karena komplikasi yang terjadi seperti kejang, selain itu juga bisa mengakibatkan hambatan pada pertumbuhan dan perkembangan anak. Salah satu pengobatan non farmakologi yang bisa dilakukan ialah kompres hangat. Tujuan riset ini untuk menganalisis pengaruh pemberian kompres hangat terhadap penurunan temperatur badan anak dengan febris. Metode penelitian ini menggunakan metode Literature Review dari artikel dikumpulkan melalui database google scholar dan academik microsoft menggunakan kata kunci febris, kompres air hangat, anak-anak termasuk studi penelitian primer, populasi berjumlah 2.362 artikel, sampel berjumlah 13 artikel. Hasil penelitian menunjukkan kalau terdapat pengaruh pemberian kompres hangat terhadap penurunan temperatur badan anak dengan febris. Kesimpulan pemberian kompres hangat dapat menurunkan temperatur badan pada anak yang mengalami febris pada anak. Saran dari peneliti bisa digunakan untuk sebagai referensi penanganan panas pada anak dengan menggunakan kompres air hangat.
\end{abstract}

\section{Kata Kunci : Anak, Febris, Kompres Air Hangat}

\begin{abstract}
Fever was a problem that often occurs in children and was the highest cause of death due to complications such as seizures, but it can also cause obstacles to the growth and development of children. One of the non-pharmacological treatments that can be done was warm compresses. The purpose of this research was to analyze the effect of giving warm compresses to decrease the body temperature in children with fever. This research method uses the Literature Review method from articles collected through the Google Scholar and Microsoft academic databases using the keywords febris, warm water compresses, children including primary research studies, the population was 2,362 articles, the sample was 13 articles. The results showed that there was an effect of giving warm compresses to the decrease in body temperature of children with fever. The conclusion of giving warm compresses can reduce body temperature in children who have
\end{abstract}


a fever in children. Suggestions from researchers can be used as a reference for handling the heat in children by using warm water compresses.

Keywords : children, Febris, Warm water compres

\section{PENDAHULUAN}

Masa anak ialah masa pertumbuhan dan masa perkembangan yang dimulai dari umur bayi (0-10 tahun), umur bermain/oddler (1-1,5 tahun), serta umur pra-sekolah (2,5-5 tahun) (Pangesti, Atmojo, \& Kiki, 2020). Dalam masa perkembangan serta pertumbuhan anak pra-sekolah ialah anak dengan umur 3-6 tahun merupakan anak dengan masa prasekolah (Wowor, Katuuk, \& Kallo, 2017). Dalam Peraturan Menteri Kesehatan RI No. 25 tahun 2014 tentang upaya dalam kesehatan anak memberi tahu jika masing-masing anak berhak atas kelangsungan hidup, tumbuh, dan berkembang serta pula berhak atas perlindungan dari kekerasan dan diskriminasi sehingga butuh dibuatnya upaya kesehatan pada anak secara terpadu, merata, serta berkesinambungan, upaya kesehatan pada anak dicoba semenjak dalam kandungan sampai anak berusia 18 tahun.

Seperti yang ditunjukkan oleh WHO (World Health Organization) menyatakan bahwa kasus demam secara keseluruhan diperkirakan mencapai 16-33 juta 500-600 ribu kematian pada tiap tahunnya. Dan di Indonesia itu sendiri angka kejadian demam pada tahun 2019 mencapai 51.480 ribu anak yang mengalami demam.
Febris adalah suatu kondisi dimana tingkat panas tubuh meningkat di atas batas normal karena peningkatan termoregulasi di pusat saraf. Sebagian besar demam pada anak disebabkan oleh pengatur suhu (termoregulasi) di pusat saraf. Demam pula berfungsi dalam tingkatkan kenaikan kerentanan eksplisit serta samar dalam menunjang pengobatan atau dalam perlindungan terhadap kontaminasi (Sodikin, 2012).

Efek demam dapat berupa hilangnya cairan tubuh secara tidak wajar, menyebabkan kekurangan cairan dan kejang. Banyak para orangtua yang percaya bahwa demam itu berbahaya bagi kesehatan anaknya karena bisa membuat kejang dan membahayakan otak (Dewi, 2016). Dalam penanganan demam pada anak berbeda bila dibanding dengan orang dewasa. karena, bila dalam merendahkan demam tidak normal serta lagi, hendak menyebabkan terhambatnya pertumbuhan serta kemajuan anak. Febris pula bisa membahayakan kesehatan anak sesungguhrnya bila tidak ditangani dengan cepat serta pas bisa menimbulkan bermacam ketidaknyamanan semacam hipertermia, kejang serta penyusutan pemahaman (Fadli \& Hasan, 2018).

Pada ayat Al-Qur'an tentang kesembuhan sesuatu penyakit pada surat Yunus ayat 57 yaitu : 

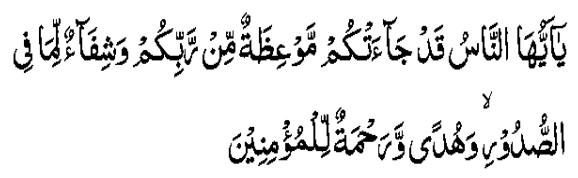

Artinya : "Wahai manusia! Sangat, sudah tiba kepadamu pelajaran (AlQur'an) dari Tuhanmu, penyembuh untuk penyakit yang terdapat dalam dada serta petunjuk dan rahmat untuk orang yang beriman.” (Q.S. Yunus : 57).

Berdasarkan pada latar belakang tersebut, hingga peneliti tertarik unuk menganalisis artikelartikel tentang pengaruh pemberian kompres hangat terhadap penurnan temperatur badan anak dengan febris umur pra-sekolah.

\section{METODE PENELITIAN}

Tinjauan pustaka pada penelitian ini menggunakan metode literature review dengan menganalisa PICOT berdasarkan pencarian artikel dari google scholar dan academic microsoft kriteria inklusi pada artikel yang diambil merupakan : publikasi 2011-2020, full paper, ISSN, postingan berbahasa Indonesia dan bahasa Inggris dengan kata kunci 'anak', 'febris', dan 'kompres air hangat'. Pencarian menghasilkan sebanyak 13 artikel yang terdiri dari google scholar sebanyak 12 artikel dan academic microsoft sebanyak 1 artikel.

\section{HASIL PENELITIAN}

Hasil analisa dari 13 artikel menunjukan kalau terdapat pengaruh pemberian kompres hangat terhadap merendahkan temperatur badan anak dengan febris, hasil analisa tersebut dapat ditampilkan pada tabel berikut :

Tabel 1

Hasil Analisa Artikel

\begin{tabular}{|c|c|c|c|c|}
\hline No & Peneliti & $\begin{array}{c}\text { Sampel dan } \\
\text { Tempat }\end{array}$ & Intervensi & Hasil \\
\hline 1. & $\begin{array}{l}\text { (Isneini, } \\
\text { Irdawati, \& } \\
\text { Agustaria, } \\
\text { 2014) }\end{array}$ & $\begin{array}{c}14 \text { Responden } \\
\text { Di Puskesmas } \\
\text { Kartasura } \\
\text { Sukoharjo }\end{array}$ & $\begin{array}{c}\text { Menurunkan } \\
\text { suhu tubuh anak } \\
\text { dengan demam } \\
\text { diberikan dua } \\
\text { terapi yaitu } \\
\text { kompres hangat } \\
\text { dan water tepid } \\
\text { sponge }\end{array}$ & $\begin{array}{l}\text { Hasil penelitian ini } \\
\text { lebih efisien } \\
\text { kompres water } \\
\text { tepid sponge dalam } \\
\text { merendahkan } \\
\text { temperatur badan } \\
\text { pada anak yang } \\
\text { hadapi demam } \\
\text { dibanding dengan } \\
\text { pemberian } \\
\text { kompres hangat. }\end{array}$ \\
\hline 2. & $\begin{array}{l}\text { (Pangesti, } \\
\text { Atmojo, \& } \\
\text { Kiki, 2020) }\end{array}$ & $\begin{array}{c}2 \text { orang anak Di } \\
\text { Ruang Tulip } \\
\text { Bangsal Anak }\end{array}$ & $\begin{array}{c}\text { Menganalisis } \\
\text { suhu tubuh pada } \\
\text { anak yang } \\
\text { mengalami } \\
\text { hipertermia }\end{array}$ & $\begin{array}{lr}\text { Hasil penelitian } \\
\text { dari } 2 \text { orang anak } \\
\text { yang } & \text { diberikan } \\
\text { kompres } & \text { hangat } \\
\text { sepanjang } 3 & \text { hari }\end{array}$ \\
\hline
\end{tabular}




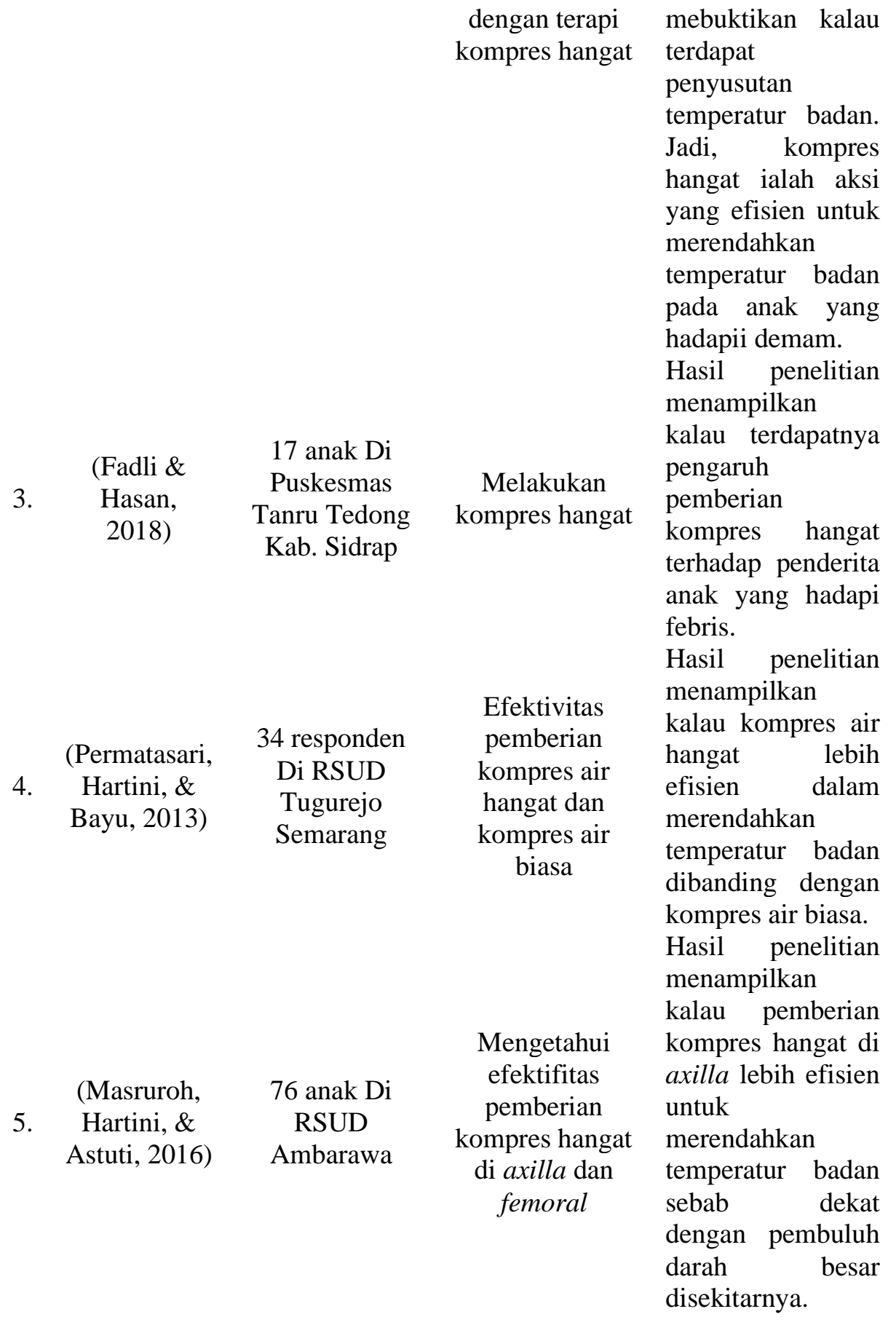


(Windawati 2 pasien dengan

6. \& Alfiyanti, diagnosa yang 2020) sama

43 sampel Di

Puskesmas

7. (Mawarti, 2019)

(Keliobas,

8.

Supratman, $\&$ Dian, 2015)

(Rahmawati

9. \& Purwanto, 2020)
Pancur Batu

Kabupaten Deli

Serdang
30 anak Di

Ruang Edelweis
RSUD

Sukoharjo
Mengetahui

gambaran

sebelum dan sesudah

pemberian

kompres air hangat
Membandingkan terapi kompres hangat dengan tepid sponge 
10. Pertiwi, 2016)

36 responden Di SMC RS Telogorejo Semarang
Melakukan kompres hangat untuk menurunkan temperatur badan

\section{(Zahroh \& \\ 20 anak Di RS \\ Pemberian}

11. Khasanah, 2017)

Wowor,

12. Katuuk, \& Kallo, 2017)
Muhammadiyah Gresik kompres hangat dan sponge bath

signifikan dalam merendahkan temperatur badan namun pengobatan kompres hangat lebih efisien dalam merendahkan temperatur badan. Hasil penelitian meampilkan kalau kompres hangat dapat merendahkan temperatur badan. Hasil menampilkan kalau pemberian sponge bath lebih efisien daripada pemberian kompres hangat dalam merendahkan temperatur badan. Hasil menampilkan kalau pemberian kompres hangat lebih efisien dalam merendahkan temperatur badan. Hasil menampilkan kompres hangat efisien dalam merendahkan temperatur badan pada anak yang hadapi demam

\section{PEMBAHASAN}

Febris merupakan reaksi tubuh terhadap suhu tubuh pada peningkatan ke kerangka tahan. Upaya dalam menjaga pengurangan tingkat panas internal harus dimungkinkan 
dengan memberikan kompres hangat (Wowor, Katuuk, \& Kallo, 2017). Kompres merupakan terapi non farmakologi yang digunakan untuk menurunkan tingkat panas pada pasien demam.untuk menurunkan tingkat panas pada pasien demam. (Fadli \& Akmal, 2018). Kompres hangat merupakan sepotong kain yang dibasahi dengan cairan hangat yang dimodifikasi (Isneini, Irdawati, \& Agustaria, 2014).

$\begin{array}{cr}\text { Berdasarkan } & \text { penelusuran } \\ \text { literatur elektronik } & \text { mengenai }\end{array}$ pemberian kompres hangat pada anak dengan demam dilatarbelakngi beberapa faktor seperti terkena influenza, kekurangan cairan, dan ada gangguan pada sistem imunitas. Berdasarkan dari 13 artikel penelitian yang dianalisis, hasilnya menunjukkan bahwa memberikan kompres hangat adalah tindakan yang layak untuk menurunkan tingkat panas. (Isneini, Irdawati, \& Agustaria, 2014), (Masruroh, Hartini, \& Astuti, 2016), (Pangesti, Atmojo, \& Kiki, 2020). Hal ini terjadi karena Tingkat panas internal dikendalikan oleh komponen input yang dimainkan oleh fokus pedoman suhu di pusat saraf atau Pusat Termoregulasi.

Penelitian ini pula didukung dengan riset Fadli \& Hasan (2018) menampilkan kalau pemberian kompres hangat efisien dalam merendahkan temperatur badan pada penderita anak yang hadapi febris. Dipaparkankan oleh Sodikin (2012) kalau pemakaian air hangat bisa melindungi penderita dari menggigil sehingga penderita tidak hadapi peningkatan tingkat panas internal karena gemetar otot. Dari kompres air hangat dapat meningkatkan vasodilatasi sehingga mempercepat siklus menghilang dan konduksi dalam tubuh yang dengan demikian dapat mengurangi tingkat panas internal. Mengenai kompres air biasa, air dingin dalam kemasan tersebut dapat membuat pasien menjadi sejuk. Dingin dari air kemasan menghambat jalan menuju menyegarkan vasodilatasi sehingga menghambat siklus menghilang dan konduksi dalam tubuh yang dengan demikian menghambat menurunkan tingkat panas internal.

Kesembuhan dalam sesuatu penyakit telah dipaparkan dalam AlQuran Surah Yunus ayat 57 yang maksudnya "Hai orang-orang! Sebetulnya sudah tiba kepadamu sesuatu amalan (Al-Qur'an) dari Penguasamu, pemecahan buat peradangan yang terdapat sebuah petunjuk di dada serta kebajikan untuk orang-orang yang menerima.." (Q.S. Yunus : 57). Dalam tafsiran Surah Yunus ayat 57 bahwa Jiwa manusia, mirip dengan tubuh, mengalami masalah dan infeksi. Dengan cara ini ia juga membutuhkan perawatan serta penyembuhan. Bermacam penyakit yang biasa terjadi pada jiwa serta raga manusia, misalnya egois, bahagia, kikir, hasud serta riya. Bila penyakit ini melanda jiwa manusia serta tidak lekas ditangani. Sehingga dapat merangsang kekufuran serta nifaq, sehingga orang dapat tersesat dari arah.

\section{SIMPULAN}

Berdasarkan hasil riset yang sudah dicoba, cenderung bisa 
disimpulkan kalau bermacam berbagai kompres yang diberikan kepada anak dengan peningkatan tingkat panas berhasil dalam menurunkan tingkat panas.. Hal ini terjadi karena perlakuan intervensi yang berbedabeda seperti kompres hangat itu bisa merangsang termoregulator yang ada di hipotalamus sehingga merenspons tubuh untuk mengatur suhu tubuh melalui radiasi dan konduksi.

\section{SARAN}

Diharapkan hasil literatur review ini bisa digunakan untuk sebagai referensi penanganan panas pada anak dengan menggunakan kompres air hangat.

\section{DAFTAR PUSTAKA}

Dewi, A. K. (2016). Perbedaan Penurunan Suhu Tubuh Antara Pemberian Kompres Air Hangat Dengan Tepid Sponge Bath Pada Anak Demam. Jurnal Keperawatan Muhammadiyah, 2-3.

Fadli, \& Hasan, A. (2018). Pengaruh Kompres Hangat Terhadap Perubahan Suhu Tubuh Pada Pasien Febris. Jurnal Ilmiah Kesehatan Pencerah (JIKP), 78-79.

Hartini, S., \& Pertiwi, P. P. (2016). Efektifitas Kompres Air Hangat Terhadap Penurunan Suhu Tubuh Anak Demam Usia 1-3 Tahun. 2-4.

Isneini, M., Irdawati, \& Agustaria. (2014). Fektifitas Penurunan Suhu Tubuh Antara Kompres Hangat Dan Water Tepid
Sponge Pada Pasien Anak Usia 6 Bulan - 3 Tahun Dengan Demam. Naskah Publikasi, 6-11.

Karra, A. K., Annas, M. A., Hafid, M. A., \& Rahim, R. (2020). The Difference Between the Conventional Warm Compress and Tepid Sponge Technique Warm Compress in the Body Temperature Changes of Pediatric Patients with Typhoid Fever. Jurnal Ners, 2-5.

Keliobas, A. A., Supratman, \& D. N. (2015). Perbandingan Keefektifan Kopmpres Tepid Sponge Dan Kompres Air Hangat Terhadap Penurunan Suhu Tubuh Pada Pada Anak Demam. Naskah Publikasi, 310.

Masruroh, R., Hartini, S., \& Astuti, R. (2016). Efektivitas Pemberian Kompres Hangat Di Axila dan Di Femoral Terhadap Penurunan Suhu Tubuh Pada Anak Demam. Jurnal Ilmu Keperawatan dan Keidanan (JIKK), 2-11.

Mawarti, S. (2019). Gambaran Suhu Tubuh Setelah Di Kompres Air Hangat Pada Anak Febris. 1-4.

Pangesti, N. A., Atmojo, B. S., \& Kiki, A. (2020). Penerapan Kompres Hangat Dalam Menurunkan Hipertermia Pada Anak Yang Mengalami Kejang Demam Sederhana. Nursing Science Journal (NSJ), 1-2. 
Permatasari, K. I., Hartini, S., \& Bayu,

M. A. (2013). Perbedaan

Efektivitas Kompres Air

Hangat dan Kompres Air

Biasa Terhadap Penurunan

Suhu Tubuh Pada Anak

Dengan Demam Di RSUD

Tugurejo Semarang, 1-2.

Rahmawati, I., \& Purwanto, D. (2020).

Efektifitas Perbedaan

Kompres Hangat dan Dingin

Terhadap Perubahan Suhu

Tubuh Pada Anak. Jurnal

Ilmiah Ilmu Kesehatan, 2-8.

Sodikin. (2012). Prinsip Perawat

Demam pada Anak.

Yogyakarta: Pustaka Belajar.

Windawati, \& Alfiyanti, D. (2020).

Penurunan Hipertermia Pada

Pasien Kejang Demam

Menggunakan Kompres

Hangat. Ners Muda, 2-7.

Wowor, M. S., Katuuk, M. E., \& Kallo,

V. D. (2017). Efektivitas

Kompres Air Suhu Hangat

Dengan Kompres Plester

Terhadap Penurunan Suhu

Tubuh Anak Demam. $e$ -

Journel Keperawatan (eKp),

2-6.

Zahroh, R., \& Khasanah, N. (2017).

Efektifitas

Pemberian

Kompres Air Hangat Dan

Sponge Bath Terhadap

Perubahan Suhu Tubuh

Pasien Anak Gastroenteritis.

Jurnal Ners LENTERA, 2-7. 